\title{
СИСТЕМАТИКА ЛИТИЕВЫХ ПЕГМАТИТОВ, ТИПИЧНЫЕ ЧЕРТЫ СТРОЕНИЯ И СОСТАВА
}

\section{Морозова Л.Н.}

Геологический институт КНЦ РАН, Anamumbl, geoksc@apatity.ru

Промышленно развитые страны сталкиваются с растущей конкуренцией в сфере производства высокотехнологичной продукции, важным компонентом которой является литий. Литий широко применяется в химической и фармацевтической промышленности, при изготовлении легких сплавов, полимеров, смазки, керамики, стекла, литиевых батареек, в атомной и термоядерной энергетике и т.д. В связи с ростом потребности в литийсодержащих источниках энергии для электромобилей к 2020 г. рынок лития может вырасти до 500 тыс. тонн. Рост производства лития отмечается за счет разработок месторождений литийсодержащих рассолов (Аргентина, Чили, Боливия, Китай, США), редкометалльных пегматитов (Австралия, Канада, Китай, Финляндия и др.) и литиевой глины (Сербия, Мексика). По данным геологической службы США, в 2016 г. лидерами по ресурсам лития являлись: Аргентина (9 млн т), Боливия (9 млн т), Чили (< 7.5 млн. т), Китай ( 7 млн. т) и США ( 6.9 млн. т). Средняя концентрация лития в рассолах варьирует от $\sim 0.14 \%$ (месторождение Салар-де-Атакама, Чили) до 0.02 \% (месторождение Saltron Sea, США), а в руде из сподуменовых пегматитов - от 1.59 \% (месторождение Гринбушес, Австралия) до 0.59 \% (месторождения Jiajika, Китай) [10].

В данной статье рассматриваются месторождения редкометалльных пегматитов лития, генетически связанные с гранитами. Характерной чертой этих месторождений является их комплексность, то есть наличие не только руд лития, но и попутных элементов: бериллия, тантала, ниобия, олова, цезия и рубидия. Поэтому, несмотря на широкое использование литийсодержащих рассолов для получения лития, роль редкометалльных пегматитов, как основного источника лития, будет сохраняться. Это связано с тем, что запасы лития в этих месторождениях достигают первых млн тонн. Например, ресурсы лития в редкометалльных пегматитах месторождения Гринбушес (Австралия) составляют 0.85 млн. тонн, а в пегматитах месторождения Кинг Маунтин (США) - 0.32 млн. тонн [11].

Литиевые пегматиты выделены в различных существующих классификациях пегматитов, что свидетельствует об их огромном значении в сырьевых ресурсах страны.

Согласно классификации П. Нигли [13], среди пегматитов выделяется 14 типов: слюдяные, гранатовые, глиноземистые, ниобий-танталовые, цирконо-титановые, боро-фтористые (турмалин), фторо-борные (топаз, турмалин), фтор-вольфрамовые, литиевые (касситерит, сподумен), марганцево-фосфатные, криолитовые, карбонатные, графитовые, сульфидные (Cu, As и др.).

По классификации А.И. Гинзбурга [2], редкометалльные пегматиты с литиевой минерализацией подразделяются на два типа: сподуменовые и сподумено-лепидолитовые. В сподуменовых пегматитах в качестве породообразующих минералов наряду с кварцем и микроклином присутствует сподумен, содержание которого может достигать 20-25 \%. В качестве попутных компонентов присутствуют: берилл, минералы группы колумбита, касситерит, петалит, амблигонит, трифилин. В сподумено-лепидолитовых пегматитах, в отличие от сподуменовых, присутствует поздний лепидолитовый замещающий комплекс, представленный лепидолитом, полихромным турмалином, амблигонитом, бериллом, поллуцитом и танталовыми минералами.

Классификация пегматитов, предложенная А.Е. Ферсманом [8], базируется на выделении пегматитов чистой линии, которые являются продуктами кристаллизации остаточного гранитного расплава, и пегматитов скрещивания (гибридные (контактовые) и десилицированные пегматиты). Пегматиты чистой линии залегают в гранитах или аналогичных породах и их состав соответствует составу материнских пород. Пегматиты линии скрещивания образуются среди пород иного состава. В этих условиях гибридные пегматиты ассимилируют вещество вмещающих боковых пород и могут содержать дистен, силлиманит, роговую обманку, пироксен, сфен, корунд. Среди пегматитов чистой линии выделяется два ряда: основной ряд пегматитов и ряд пегматитов заполнения миароловых пустот. К основному ряду относятся следующие пегматиты: I) обычные и церовые (монацитовые, ортитовые, гранатовые, без минерализации); II) с редкими элементами (U, Nb, Ta, Y, TR и др.); 
III) боро-фтористые (шерловые, мусковитовые); IV) фторо-бериллиевые (берилловые, топазовые); V) натрово-литиевые (альбитовые, лепидолито-рубеллитовые); VI) марганцево-фосфатные (железомарганцево-фосфатные без лития; литио-железо-марганцево-фосфатные); VII) фторо-алюминиевые (альбит-жильбертитовые; фосфато-карбонатные; криолитовые); VIII) фторо-карбонатные; IX) сульфидные; Х) щелочные.

Классификация К.А. Власова [1] основана на текстурно-парагенических признаках, согласно которым пегматиты подразделяются на следующие типы: графические, блоковые, полнодифференцированные, редкометалльно-замещенные и альбит-сподуменовые. По классификации Н.А. Солодова [7] разделение пегматитов осуществляется по соотношению породообразующих минералов: микроклина, сподумена и альбита, что позволяет выделить следующие типы пегматитов: микроклиновые, микроклин-альбитовые, альбитовые, альбит-сподуменовые, амазонит-альбитовые, микроклин-петалитовые, мусковит-альбитовые и лепидолит-альбитовые.

Согласно классификации В.Е. Загорского, В.М. Макагона и Б.М. Шмакина [4], гранитные пегматиты подразделяются на пять формаций: редкометалльно-редкоземельную, редкометалльную, слюдоносную и полевошпатовую. Среди пегматитов редкометалльной формации выделяются петалитовая и сподуменовая подформации, в составе которых выделяются минерагенические эволюционные ряды и парагенические типы (табл. 1).

Таблица 1. Классификация редкометалльных пегматитов по [4].

\begin{tabular}{|c|c|c|c|}
\hline Формация & Подформация & Минерагенический эволюционный ряд & Парагенетический тип \\
\hline \multirow{10}{*}{ 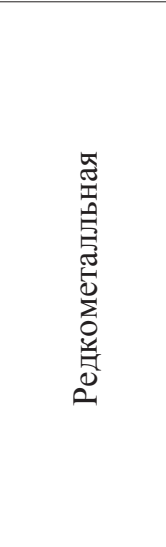 } & \multirow{5}{*}{ 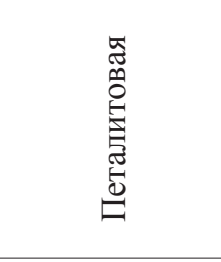 } & Цезий-тантал-литиевый (комплексный) & Петалит-калишпат-альбитовый \\
\hline & & Фтор-тантал-литиевый & Лепидолит-альбитовый \\
\hline & & Фосфор-тантал-литиевый & Амблигонит-альбитовый \\
\hline & & Литиевый & Петалит-калишпат-альбитовый \\
\hline & & Бериллиевый & Альбитовый \\
\hline & \multirow{5}{*}{ 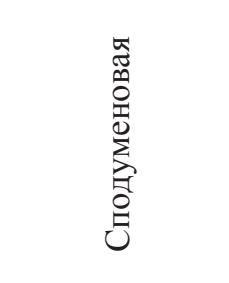 } & Цезий-тантал-литиевый (комплексный) & Сподумен-калишпат-альбитовый \\
\hline & & Фосфор-тантал-литиевый & $\begin{array}{l}\text { Монтебразит-сподумен-калишпат- } \\
\text { альбитовый }\end{array}$ \\
\hline & & Тантал-олово-литиевый & Сподумен-калишпат-альбитовый \\
\hline & & Литиевый & Сподумен-калишпат-альбитовый \\
\hline & & Тантал-бериллиевый & Альбитовый \\
\hline
\end{tabular}

В зарубежной литературе наиболее распространена классификация П. Черны и Т.С. Эрсита [9], основанная на разделении пегматитов на пять классов: абиссальный, мусковитовый, мусковитредкометалльный, редкометалльный и миароловый. Класс редкометалльных пегматитов LCT семейства в зависимости от геохимической специализации пород подразделяется на типы и подтипы (табл. 2).

Таким образом, исходя из того какую классификацию использует автор, характеристика литиевых пегматитов может быть различной. Например, согласно классификациям Н.А. Солодова и К.А. Власова, по внутреннему строению жил и соотношению породообразующих минералов пегматиты Колмозерского литиевого месторождения относятся к альбит-сподуменовому типу. По классификации А.Е. Ферсмана пегматиты Колмозерского месторождения соответствуют пегматитам натроволитиевого типа, по классификации П. Черны и Т.С. Эрсита - редкометалльным пегматитам LCT семейства, альбит-сподуменовому типу, а по классификации Е.В. Загорского с соавторами - редкометальной формации, подформации сподуменовых пегматитов, литиевому эволюционному ряду.

Среди редкометалльных литиевых месторождений наиболее масштабными являются месторождения редкометалльных пегматитов альбит-сподуменового и комплексного типа. По сравнению с комплексным типом $(\mathrm{Li}=37-8400$ г/т) редкометалльные пегматиты альбит-сподуменового типа имеют ураганные содержания лития $(\mathrm{Li}=5110-10310$ г/т). Пегматиты альбит-сподуменового типа характеризуются высоким содержанием рудных элементов ( $\mathrm{Li}, \mathrm{Nb}, \mathrm{Ta}, \mathrm{Be})$, а также $\mathrm{Rb}, \mathrm{SiO}_{2}$ и $\mathrm{Al}_{2} \mathrm{O}_{3}$, 
преобладанием $\mathrm{Na}_{2} \mathrm{O}$ над $\mathrm{K}_{2} \mathrm{O}$, низким содержанием $\mathrm{TiO}_{2}, \mathrm{CaO}, \mathrm{MnO}, \mathrm{MgO}$, крупноионных литофильных (Sr, Ba) и высокозарядных (Y, Zr, REE) элементов. Графики распределения редкоэлементных элементов имеют слабо фракционированный спектр с отрицательной европиевой аномалией. На мультиэлементных трендах распределения редких элементов отмечаются положительные аномалии $\mathrm{Li}, \mathrm{Be}, \mathrm{Nb}, \mathrm{Ta}, \mathrm{Cs}, \mathrm{Rb}, \mathrm{U}, \mathrm{Sr}$ и $\mathrm{Hf}$ и отрицательные аномалии $\mathrm{Ba}, \mathrm{Th}$ и $\mathrm{Eu}$ [5].

Таблица 2. Классификация редкометалльных пегматитов по [9].

\begin{tabular}{|c|c|c|c|c|c|}
\hline 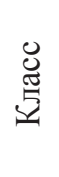 & 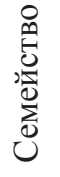 & 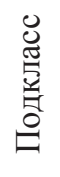 & Тип & Подтип & Геохимическая специализация \\
\hline \multirow{9}{*}{ 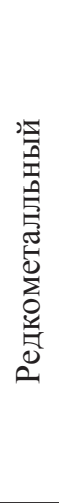 } & \multirow{9}{*}{ 㫐 } & \multirow{9}{*}{ 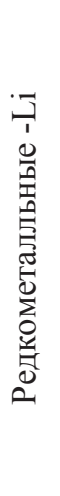 } & \multirow[b]{2}{*}{ Берилловый } & Берилл-колумбитовый & $\mathrm{Be}, \mathrm{Nb}><\mathrm{Ta}( \pm \mathrm{Sn}, \mathrm{B})$ \\
\hline & & & & $\begin{array}{l}\text { Берилл-колумбит- } \\
\text { фосфатный }\end{array}$ & $\mathrm{Be}, \mathrm{Nb}><\mathrm{Ta}, \mathrm{P}(\mathrm{Li}, \mathrm{F}, \pm \mathrm{Sn}, \mathrm{B})$ \\
\hline & & & \multirow{5}{*}{ Комплексный } & Сподуменовый & $\mathrm{Li}, \mathrm{Rb}, \mathrm{Cs}, \mathrm{Be}, \mathrm{Ta}><\mathrm{Nb}(\mathrm{Sn}, \mathrm{P}, \mathrm{F}, \pm \mathrm{B})$ \\
\hline & & & & Петалитовый & $\mathrm{Li}, \mathrm{Rb}, \mathrm{Cs}, \mathrm{Be}, \mathrm{Ta}>\mathrm{Nb}(\mathrm{Sn}, \mathrm{Ga}, \mathrm{P}, \mathrm{F}, \pm \mathrm{B})$ \\
\hline & & & & Лепидолитовый & $\mathrm{F}, \mathrm{Li}, \mathrm{Rb}, \mathrm{Cs}, \mathrm{Be}, \mathrm{Ta}>\mathrm{Nb}(\mathrm{Sn}, \mathrm{P}, \pm \mathrm{B})$ \\
\hline & & & & Эльбаитовый & Li, B, Rb, Sn, F (Be, Ta, Cs) \\
\hline & & & & Амблигонитовый & $\mathrm{P}, \mathrm{F}, \mathrm{Li}, \mathrm{Rb}, \mathrm{Cs}, \mathrm{Be}, \mathrm{Ta}>\mathrm{Nb}(\mathrm{Sn}, \pm \mathrm{B})$ \\
\hline & & & Альбит-сподуменовый & & $\mathrm{Li}(\mathrm{Sn}, \mathrm{Be}, \mathrm{Ta}><\mathrm{Nb}, \pm \mathrm{B})$ \\
\hline & & & Альбитовый & & $\mathrm{Ta}><\mathrm{Nb}, \mathrm{Be}(\mathrm{Li}, \pm \mathrm{Sn}, \mathrm{B})$ \\
\hline
\end{tabular}

Примерами крупных месторождений редкометалльных пегматитов альбит-сподуменового типа являются месторождения Кингс-Маутин (Северная Каролина, США;), Вольта-Гранде (Бразилия), Колмозерское (Кольский полуостров, Россия), Тастыгское (Тува, Россия), Завитинское (Восточное Забайкалье, Россия). К месторождениям редкометалльных пегматитов комплексного типа относятся месторождение Танко (Манитоба, США), Бикита (Зимбабве), Гринбушес (Австралия), Гольцовое (Восточные Саяны, Россия), Коктогай (Китай).

Редкометалльные пегматиты альбит-сподуменового типа, как правило, представлены слабо зональными жилами пегматитов, в то время как комплексный тип - жилами пегматитов с хорошо выраженной зональностью.

Месторождение Кингс Маунтин [11] слагают крутопадающие жильные тела длиной до 1000 м мощностью до 90 метров, залегающие субпараллельно среди амфиболитов и слюдистых сланцев. В строении слабо зональных жил пегматитов выделяется: а) тонкая кварц-альбитовая оторочка; б) маломощная промежуточная зона аплита с прослоями калишпатового пегматита; в) центральная зона, сложенная мелкозернистым кварц-альбит-мусковитовым агрегатом со столбчатыми кристаллами калиевого полевого шпата и сподумена, длина которого достигает 1 метра. Породообразующие минералы пегматитов: кварц, калиевый полевой шпат, альбит, сподумен, мусковит. Акцессорные минералы: берилл, касситерит, амблигонит, лепидолит, группа колумбита, вольфрамит.

Основной объем (75-80 \%) слабо зональных жил редкометалльных пегматитов Вольта Гранде сложен кварц-сподумен-альбит-микроклиновым пегматитом с мусковитом, в котором кристаллы сподумена достигают 50-100 см в длину [12]. Слабо зональные жилы Колмозерского литиевого месторождения представлены крупно- и гигантозернистым кварц-сподумен-полевошпатовым пегматитом, на долю которого приходится до 85-90 \% объема жил. К этой зоне приурочены рудные минералы группы колумбита, берилл, сподумен, достигающий до 1.5 м в длину $[3,5,6]$.

Месторождение Коктогай [14] представлено тридцатью пологозалегающими пегматитовыми телами, секущими метагабброиды. Пегматиты расположены вблизи лейкократовых мусковитовых гранитов, которые являются источниками редкометалльных пегматитов. Жильные тела имеют до десяти зон, которые различаются по минеральному составу и структурно-текстурным особенностям. В строении наиболее детально изученной жилы № 3 выделяются следующие зоны: 
1) кварц-микроклиновая графической и неяснографической структуры; 2) сахаровидного альбита; 3) микроклиновая массивной структуры; 4) мусковит-кварцевая; 5) сподумен-альбитовая; 6) сподумен-кварцевая; 7) мусковит-альбиттовая; 8) альбит-лепидолитовая; 9) кварцевое ядро с моноблоками микроклина. Рудные минералы: сподумен, поллуцит, группа колумбита, берилл. Наиболее распространенные минералы: флюорит, турмалин, топаз, пирит, магнетит, спессартин, амблигонит. Таким образом, определение литиевых пегматитов в ряду различных классификаций является их важной характеристикой, позволяющей определить тип (подтип) пегматитов.

Работа выполнена в рамках госзадания по теме НИР 0231-2015-0001.

\section{Литература}

1. Власов К.А. Принципы классификации гранитных пегматитов и их текстурно-парагенетические типы // Изв. АН СССР. Сер. геол. 1961. № 1. С. 8-29.

2. Гинзбург А.И. Минералого-геохимическая характеристика литиевых пегматитов // Тр. Минералогического Музея. Вып. 7. 1955. С. 12-55.

3. Гордиенко В.В. Минералогия, геохимия и генезис сподуменовых пегматитов. Л.: Недра, 1970. 240 с.

4. Загорский В.Е., Макагон В.М., Шмакин Б.М. Систематика гранитных пегматитов // Геология и геофизика. 2003. Т. 44. № 5. С. 422-435.

5. Морозова Л.Н. Колмозерское литиевое месторождение редкометалльных пегматитов: новые данные по редкоэлементному составу (Кольский полуостров) // Литосфера. 2018. Т. 18. № 1. С. 82-98.

6. Морозова Л.Н., Баянова Т.Б., Базай А.В., Лялина Л.М., Серов П.А., Борисенко Е.С., Кунаккузин Е.Л. Редкометалльные пегматиты Колмозерского литиевого месторождения Арктического региона Балтийского щита: новые геохронологические данные // Вестник Кольского научного центра РАН. 2017. С. 43-52

7. Солодов Н.А. Внутреннее строение и геохимия редкометальных гранитных пегматитов. Изд-во АН СССР, 1962. $234 \mathrm{c}$.

8. Ферсман А.Е. Пегматиты. М., Изд-во АН СССР, 1952. 712 с.

9. Černý P., Ercit T.S. Classification of granitic pegmatites: Canadian Mineralogist. V. 43. Rare-element granitic pegmatites. Part 1: Anatomy and internal evolution of pegmatite deposits // Geoscience Canada. 2005. V. 18. № 2. P. 49-67.

10. Gruber P.W., Medina P.A., Keoleian G.A., Kesler S.E., Everson M.P., Wallington T.J. Global Lithium Availability // Journal of Industrial Ecology. 2001. P 1-16.

11. Kesler S.E., Gruber P.W., Medina P.A., Keoleian G.A., Everson M.P., Wallington T.J. (2012) Global lithium resources: Relative importance of pegmatite, brine and other deposits //Ore Geology Reviews. № 48. 55-69.

12. Lagache M. The Volta Grande pegmatites, Minas Gerais, Brazil: an example of rate-element granitic pegmatites exceptionally enriched in lithium and rubidium // The Canadian Mineralogist. 1997. № 35. P. 153-165.

13. Niggli P. Die Leichtfluchtigen Bestandteile in Magma // Hreisschr. Jablonow. Ges. 1920. № 47. P. 165-230.

14. Zhu Y.-F., Zeng Y., Gu L. Geochemistry of the rare metal-bearing pegmatite No. 3 vein and related granites in the Keketuohai region, Altay Mountains, northwest China // J. of Asian Earth Sciences. 2006) №. 27. P. 61-77. 